Vol. 3, n 1 | 1999

Varia

\title{
Clive Emsley, Crime and Society in England 1750-1900
}

London and New York, Longman, 1996 ( $2^{\text {nd }}$ ed.), 287 p., ISBN 0522

25768-9

Martin J. Wiener

\section{(2) OpenEdition}

Electronic version

URL: https://journals.openedition.org/chs/944

DOI: $10.4000 /$ chs. 944

ISSN: 1663-4837

Publisher

Librairie Droz

Printed version

Date of publication: 1 January 1999

Number of pages: 131-132

ISBN: 2-600-00356-8

ISSN: $1422-0857$

\section{Electronic reference}

Martin J. Wiener, "Clive Emsley, Crime and Society in England 1750-1900", Crime, Histoire \& Sociétés /

Crime, History \& Societies [Online], Vol. 3, n¹ | 1999, Online since 03 April 2009, connection on 23

March 2022. URL: http://journals.openedition.org/chs/944 ; DOI: https://doi.org/10.4000/chs.944

(c) Droz 
own, and seemed to be generally accepted. This raises a further point. Much of the writing on Enlightenment law reform seems to be constrained within what an Anglosphone historian would describe as a Whig Interpretation: that is, an occasionally triumphalist history which takes an uncritical celebration of progress as its main theme. People in the past were not quite as enthusiastic for progress, or at least change, as are modern historians, and there must be a large question as to how far judges and the perhaps relatively unenlightened local law enforcement officers to whom I have referred reacted to the changes proposed by their rulers and the intellectuals whom, in the eighteenth century, it was fashionable to trust as policy makers. Again, we need to know more about the personnel manning Europe's criminal justice systems, the attitudes of such people, and how those machines actually operated.

But between them these do books have done us a valuable service. D'où vient le code pénal? Has provided us with a thoughtful, scholarly, yet lively and wide ranging restatement of what is, in essence, the traditional framework for the legal history of Ancien Régime Europe. The collection edited by Porret, while celebrating what has long been accepted as a key figure in that traditional history, does contain many pointers to how future research might move beyond that framework, and deepen our understanding of this important and fascinating aspect of Europe's past.

\section{J.A. Sharpe \\ (University of York, England) \\ jas19@york.ac.uk}

Clive Emsley, Crime and Society in England 1750-1900, London and New York, Longman, 1996 ( $2^{\text {nd }}$ ed.), 287 p., ISBN 0522 25768-9.

The first edition of this work, bringing together for the first time the findings of specialized scholarship in a concise overview of the subject, immediately became a standard reference. In less than a decade, the large amount of scholarly work in the decade since has called forth a revised edition, one which maintains the work's position as an indispensable introduction to the field. Like its predecessor, this edition provides not only authoritative brief summaries of specialized research (including the author's own), but a most attractive text for undergraduate and graduate students. Emsley has managed to marry precision of exposition with the vividness of a multitude of examples drawn from the archives. The original edition is updated throughout, as findings and arguments of work done in the intervening decade are smoothly incorporated -including some work not yet published. As the focus within the field has moved from crime as a social activity to how crime was defined and dealt with, Emsley's chapters on these subjects have become richer, without giving up the clarity of the first edition.

The most important difference between editions is the addition here of an entirely new chapter on gender, a perspective that was barely acknowledged a decade ago. This chapter opens with Frances Heidensohn's apt observation that, even more than class, gender is «the crucial variable in predicting criminality.» Yet the over- 
whelmingly male nature of most criminal activity was just what allowed gender to be dismissed by earlier scholars. Crime was an affair of men, and that acknowledgment was the beginning and end of the gender issue. Now, however, that «fact » is seen to raise, not close, questions central to the entire enterprise of criminal history. The perspective of gender affects the older history of crime in two ways. First, Emsley brings women fully into the story. He examines criminal activity by women (chiefly petty theft and offences associated with prostitution) and against women (in particular domestic violence and sexual assault). Such activities (usually very under-reported) have traditionally but not necessarily correctly been seen as either trivial or "private," and thus of less broad import than others (which generally involve few women) like rioting, poaching, forgery, robbery or murder. He also describes evidence for a long-term decline during this period in female criminal participation and notes possible explanations recently advanced. Second - and here the scholarship does not yet support an extended discussion, so Emsley is very brief looking closely at gender opens up fresh questions about how behavior is criminalized, and how it may be differentially treated, by police, courts and penal systems. In these questions the increasing interest in gender dovetails with that in how crime is defined and dealt with. Perhaps in another decade a third edition of this work may be able to provide a fuller discussion of these questions.

In the meantime, we are fortunate to have Emsley's work as a judicious and knowledgeable marker of the present state of modern English criminal justice history.

\section{Martin J. Wiener \\ (Rice University)}

Lonza (Nella), Pod plaštem pravde, Kaznenopravni sustav Dubrovaèke Republike u XVIII. stoljecu, (Sous le voile de la justice, Le système pénal de la République de Dubrovnik au XVIII ${ }^{e}$ siècle) Dubrovnik, Zavod za povijesne znanosti Hrvatske Akademije Znanosti i Umjetnosti (Publications de l'Institut pour les Sciences historiques de l'Académie des Sciences de Croatie), 1997, [Résumé en anglais], ISBN 9531540810 .

Cet ouvrage sérieux, bien documenté sur les archives de la République ragusienne, analyse différents aspects de son système pénal. Au confluent de multiples influences, la doctrine se construit déjà au XII ${ }^{\mathrm{e}}$ siècle et s'enrichit par acquis et emprunts successifs au système pénal vénitien, ainsi qu'à la coutume ou encore à la jurisprudence des villes italiennes. La torture par exemple, dont la pratique et la doctrine sont empruntées aux villes italiennes, est utilisée au XIV ${ }^{e}$ siècle alors que les normes écrites n'existent pas encore. Les premiers cadres, notaires, viennent des villes italiennes, avec lesquels perdurent des liens sociaux. Les grandes familles de Dubrovnik (comme les Sorgo) forment au courant du XVIII siècle volontiers leurs fils à Rome, ou à Bologne. La doctrine juridique italienne s'y répand à la même vitesse qu'ailleurs en Europe; le texte de Beccaria, Des délits et des peines, dans son édition vénitienne de 1781, arrive la même année dans les villes de la côte dalmate.

En analysant la structure de l'appareil juridique, le fonctionnement de ses institutions, la pratique pénale et son insertion dans le tissu social, Lonza dresse un 